DOI: $10.17951 / \mathrm{fb} .2018 .60 .187-207$

\title{
Karol Ebertowski
}

Instytut Informacji Naukowej i Bibliologii

Uniwersytet Mikołaja Kopernika w Toruniu

https://orcid.org/0000-0002-7968-1763

\section{BAZY GENEALOGICZNE JAKO POMOC W POSZUKIWANIU PRZODKÓW}

\begin{abstract}
Streszczenie: Genealogia, chociaż uważana za jedną z nauk pomocniczych historii, coraz częściej wymaga nowoczesnego podejścia i nowych możliwości upowszechnienia przekazywanej informacji. Genealogiczne bazy danych doskonale się do tego nadają i stają się przez to coraz bardziej powszechne. Celem niniejszego artykułu jest charakterystyka sześciu wybranych baz genealogicznych, omówienie okoliczności powstania i rozwoju, zasad gromadzenia materiału oraz ich funkcjonalności, w tym udostępniania danych, możliwości przeszukiwania ich zasobów oraz filtrowania rezultatów wyszukiwania. Autor wyjaśnił, jak należy definiować i postrzegać genealogiczne bazy danych, jak klasyfikować ich zasoby oraz w jaki sposób z nich korzystać.
\end{abstract}

Słowa kluczowe: bazy danych, wyszukiwarki, genealogia, Internet, rodzina

\section{Genealogical Databases as Help in Searching for Ancestors}

\begin{abstract}
Genealogy, although considered as one of the auxiliary sciences of history, more and more often requires a modern approach and new possibilities of disseminating information transmitted. Genealogical databases are perfect for this and are becoming more and more common. The following text aims to familiarize a potential user with these databases, show the principles of operation and collection, share data contained therein, the ability to search their resources, correctly read the results. Before that, however, it explains what genealogical databases are, what their typology is and how they fit into the divisions and hierarchies already established. Six bases are described here along with the rules of their operation, showing the search possibilities (or their absence), filtering/sorting results and other options of use.
\end{abstract}

Keywords: databases, search engines, genealogy, Internet, family 


\section{Wprowadzenie}

W dobie powszechnej informatyzacji i popularyzacji Internetu genealogia, będąca nomen omen jedną z nauk pomocniczych historii, nie pozostaje w tyle względem rozwoju technologii i możliwości przekazu informacji specjalistycznej. W ustalaniu wiedzy o rodzinie nieocenionymi źródłami są bazy danych - zarówno te stricte nastawione na gromadzenie i upowszechnianie skanów dokumentów z Urzędów Stanu Cywilnego i parafii kościelnych, jak i te powstałe przez zindeksowanie wpisów z takich ksiąg. Wydaje się, że zwłaszcza bazy danych nastawione na przechowywanie i udostępnianie informacji genealogicznej w Internecie, takie jak choćby baza Pomorskiego Towarzystwa Genealogicznego (ptg.gda.pl), Geneteka (geneteka. genealodzy.pl), Metryki (metryki.genbaza.pl), Genealogia w archiwach (genealogiawarchiwach.pl), Szukaj w archiwach (szukajwarchiwach.pl) czy FamilySearch (familysearch.org) są skarbnicą wiedzy jeszcze nieodkrytej.

Celem artykułu jest przybliżenie zasad funkcjonowania wyżej wymienionych baz, zaprezentowanie wskazówek pomocnych w sposobie poruszania się po nich, prawidłowym wyszukiwaniu w ich zasobach oraz odczytywaniu otrzymanych wyników.

\section{Znaczenie terminu „baza danych”}

W dzisiejszych czasach za każdą witryną, stroną, portalem, serwisem internetowym działa baza danych przechowująca i udostępniająca ogromne ilości danych. Poświęcono mnóstwo stron w literaturze, aby zdefiniować, czym jest baza danych. Nie ma jednej powszechnie obowiązującej definicji tego terminu. Każdy bowiem wskazuje na inne, ważne jej aspekty.

Samo pojęcie „baza danych” (ang. database, dalej: $\mathrm{BD}$ ) pojawiło się już w latach 60. XX w. jako „odpowiedź na wymagania użytkowników komputerów, związane ze sposobem przechowywania danych w pamięciach zewnętrznych komputera, jak i sposobem dostępu do tych danych"'. Jak podali Paweł Urbanowicz, Marcin Płonkowski, Dmitry Urbanowicz, bazą danych można określić „zbiór powiązanych ze sobą danych o określonej strukturze, zapisany na zewnętrznym nośniku pamięci komputera, który może zaspokoić wymagania wielu użytkowników, korzystających z niego w sposób selektywny w dogodnym dla siebie czasie [...] umożliwia centralizację, koordynację i integrację informacji oraz przesyłanie ich wielu użytkownikom”. W skład tak rozumianej bazy danych wchodzą cztery elementy:

1 P. Urbanowicz, M. Płonkowski, D. Urbanowicz, Bazy danych. Teoria i praktyka. Podręcznik dla studentów szkół wyższych, Lublin 2010, s. 13. 
- zbiór,

- struktura,

- związki,

- użyteczność.

Autorzy wyjaśnili, że BD jest zbiorem zawierającym ważne i użyteczne dla użytkowników informacje, ustrukturyzowanym według przyjętego modelu bazy danych, zapewniającym reprezentację związków logicznych zachodzących pomiędzy tymi informacjami i ich elementami².

Nieco inaczej istotę BD opisała Izabela Rojek-Mikołajczak w książce Bazy danych. Kurs podstawowy dla inżynierów informatyki. Autorka zaczęła od zdefiniowania, czym jest „dana” (absolutny fakt zapamiętany w bazie, np. miejsce, liczba, wydarzenie itp.) i „informacja” (dana przetworzona w sposób pozwalający na podejmowanie logicznych decyzji). Następnie wymieniła cechy, którymi wyróżnia się baza danych, tj. uporządkowany zbiór danych wzajemnie ze sobą powiązanych, nieredundantnych (nadmiarowych), wspólnie kontrolowanych, integralnych i logicznie spójnych. Podkreśliła też, że baza odnosi się do pewnego ustalonego fragmentu rzeczywistości, co ogranicza krąg użytkowników³.

Ciekawą kwestię baz danych omówiła Małgorzata Kowalska, która na podstawie istniejącego piśmiennictwa fachowego w artykule Zasoby czasopiśmiennicze $w$ polskich bibliotekach cyfrowych i bibliograficznych bazach danych - koegzystencja, konkurencja czy kooperacja? porównała właściwości baz danych, repozytoriów i bibliotek cyfrowych. Autorka za Zdzisławem Płońskim przytoczyła, że BD to „zbiór wzajemnie powiązanych danych opisujących pewien wybrany fragment rzeczywistości, wyposażony w oprogramowanie umożliwiające ich definiowanie, wykorzystywanie i modyfikowanie"4. Następnie zacytowała Bożenę Bojar, pisząc, że baza danych to „uporządkowany zbiór informacji (opisowych i content units) z określonej dziedziny lub tematyki, ze wspólnym interfejsem użytkownika i oprogramowaniem przeznaczonym do wyszukiwania i przetwarzania danych"s. Autorka słusznie zauważyła, że bazy danych coraz częściej przejmują cechy charakterystyczne innych zasobów elektronicznych, chcąc z nimi konkurować, a granice pomiędzy bazą danych, repozytorium a biblioteką cyfrową się zacierają.

2 Tamże.

3 I. Rojek-Mikołajczak, Bazy danych. Kurs dla inżynierów informatyki, Bydgoszcz 2004, s. 9.

${ }^{4}$ M. Kowalska, Zasoby czasopiśmiennicze w polskich bibliotekach cyfrowych i bibliograficznych bazach danych - koegzystencja, konkurencja czy kooperacja?, [w:] Bibliograficzne bazy danych: kierunki rozwoju i możliwości współpracy, Ogólnopolska konferencja naukowa z okazji 10-lecia bazy danych BazTech. Bydgoszcz, 27-29 maja 2009 r., [online]. Dostępny w World Wide Web: http://www.ebib.pl/ publikacje/matkonf/mat19/kowalska.php [dostęp: 27.05.2018].

5 Tamże. 
Na dwie istotne cechy baz danych - trwałość (dane przechowywane bez terminu ważności) i zgodność z rzeczywistością (implikująca zmiany w bazie na podstawie zmian rzeczywistości) uwagę zwrócili także Lech Banachowski i Krzysztof Stencel ${ }^{6}$.

W podobnym tonie wypowiedział się również Marek Krajewski, który we wprowadzeniu do Wizualnych baz danych wskazał, iż większość współczesnych informacji jest reprezentowana przez obrazy, reprodukcje, zdjęcia itp. Problematyczne staje się ich gromadzenie, kolekcjonowanie, a co za tym idzie również upowszechnianie. Analiza tak rozumianej wizualności jest coraz bardziej niezbędna do badań nad współczesnością ${ }^{7}$ Każdy obraz, jego reprodukcja, skan fotografii itp. jest oceniany przez każdego odbiorcę i obserwatora indywidualnie, subiektywnie. Dopiero jego opis staje się podstawą do poprawnego zbadania jego oddziaływania na społeczeństwo. Coraz częściej digitalizowane dokumenty życia społecznego, sprawozdania, księgi, metryki, akta itp. są poddawane rozpoznaniu techniką OCR, przez co zyskują dodatkowe atrybuty pomocne w badaniach nad określonym wycinkiem rzeczywistości.

\section{Specyfika genealogicznych baz danych}

Genealogiczne bazy danych są stosunkowo nowym zagadnieniem z zakresu bazodanowego, dlatego też oficjalnie nie mają jeszcze swojej definicji ani miejsca w topologii bazodanowej. Nie można ich również bezpośrednio przyporządkować do podziału już przyjętego, tj. baz pełnotekstowych, tekstowych, numerycznych, abstraktowych czy faktograficznych, ponieważ można w nich odnaleźć cechy charakterystyczne każdej z nich. Pełnotekstowość objawia się w możliwości przeszukiwania bazy za pomocą słów kluczowych oraz przeglądania pełnej zawartości źródeł genealogicznych. Aspekt numeryczności baz genealogicznych jest odzwierciedlony w podstawowych dla genealogii danych, takich jak daty urodzeń, ślubów, zgonów czy po prostu wiek opisywanej osoby, liczba małżonków, dzieci itp. Abstraktowość zawiera się z kolei we wszelkiego rodzaju odniesieniach pomiędzy danymi zawartymi w bazach, np. wpisany w bazie tekstowej numer aktu małżeństwa jest wskazówką do wyszukania skanu ze zdigitalizowaną wersją tego aktu w bazie graficznej. Wreszcie faktograficzność genealogicznych baz danych objawia się w rodzaju przechowywanych danych - faktach historycznych.

${ }^{6}$ L. Banachowski, K. Stencel, Bazy danych. Projektowanie aplikacji na serwerze, Warszawa 2001, s. 7.

M. Krajewski, Wprowadzenie, [w:] Człowiek i społeczeństwo. Wizualne bazy danych, red. M. Krajewski, Poznań 2013, s. 192. 
Zdefiniowanie genealogicznej bazy danych jest równie problematyczne jak umieszczenie jej w powszechnie przyjętej typologii BD. Wiele elementów istniejących w tego rodzaju bazie jest zarówno ich zaletą, jak i wadą. Gdyby przez analogię do terminu „baza danych” spróbować zdefiniować pojęcie „genealogiczna baza danych", wówczas można by było ogólnie przyjąć, że baza genealogiczna to baza gromadząca, przechowująca, udostępniająca informację genealogiczną. Mimo że taka definicja zasadniczo nie odbiegałaby od prawdy, wydaje się ona zbyt ogólna i praktycznie niewiele mówiąca potencjalnemu użytkownikowi. Warto by więc ją doprecyzować, tym bardziej że dotychczas nie została dostatecznie wypracowana.

„Genealogiczną bazą danych” (dalej: GBD) powinno się określać zbiór informacji odnoszących się do wydarzeń z życia każdego człowieka, opisanych za pomocą faktów genealogicznych: podstawowych (jak imię, nazwisko oraz daty i miejsca urodzenia, ślubu, zgonu) i dodatkowych (często opcjonalnych, dobieranych przez twórcę bazy), tj. dat i wydarzeń związanych z tymi pierwszymi, jak np. daty przyjęcia innych sakramentów świętych, okresy edukacji, miejsca pobytu i zamieszkania. W GBD każdy fakt genealogiczny wskazuje się przez podanie: daty zdarzenia, miejsca zdarzenia, danych identyfikujących osoby w nim uczestniczące i danych identyfikujących źródło informacji.

Ze względu na brak faktycznego, ścisłego podziału GBD, na potrzeby artykułu wprowadzono dwa sposoby kategoryzacji. Pierwszy z nich opiera się głównie na sposobie zapisu, przechowywania i udostępniania informacji genealogicznej potencjalnemu użytkownikowi. Wyróżniono tutaj:

- GBD z informacją podaną w formie tekstowej,

- GBD z informacją podaną w formie graficznej.

Wariant tekstowy jest wynikiem transkrypcji oryginalnego, ręcznie spisanego aktu, metryki czy wpisu w księdze na pismo komputerowe i finalnego zamieszczenia go w bazie. Graficzność zaś jest następstwem digitalizacji wymienionych wyżej dokumentów i umieszczenia skanów w bazie. Trzeba tutaj zaznaczyć, że niektóre opisy wprowadzone w bazach tekstowych są odnośnikami (hiperłączami) konkretnych skanów w bazach graficznych, co pozwala na lepsze i szybsze, a co za tym idzie wygodniejsze poruszanie się po obu rodzajach baz.

Drugi podział GBD bazuje na pochodzeniu informacji zamieszczonej w bazie. Innymi słowy - skąd pochodzi i/lub gdzie jest przechowywana informacja genealogiczna. Są to GBD z informacjami pochodzącymi z:

- archiwów państwowych,

- archiwów kościelnych,

- innych jednostek archiwalnych.

W przypadku archiwów państwowych uwaga twórców baz skupia się głównie na urzędach stanu cywilnego, następnie na szkołach i ośrodkach wychowawczych. 
Jeśli chodzi o archiwa kościelne, najczęściej uwzględniane są dane pochodzące z parafii, później dekanatów i diecezji. Dobór innych jednostek archiwalnych pozostaje w kwestii osób odpowiedzialnych za zarządzanie zasobami, którymi dane archiwum operuje, i to w jak wielkim stopniu je udostępnia.

Bez względu na pochodzenie czy sposób i miejsce przechowywania danych genealogicznych wszystkie bazy genealogiczne są tworzone przez jednostki pośrednio lub bezpośrednio związane z polskimi towarzystwami genealogicznymi i heraldycznymi. Zazwyczaj są to osoby z wykształceniem z zakresu historii, bibliotekoznawstwa, sztuki, archiwistyki, geografii, z którymi współpracują ci o zupełnie innych profesjach, ale o wspólnym hobby - genealogii.

Przegląd wybranych genealogicznych baz danych

Poniżej przedstawiono wybrane GBD specjalizujące się w gromadzeniu, przechowywaniu i udostępnianiu informacji związanych z powiązaniami rodzinnymi (koicji i filiacji, pokrewieństwami i powinowactwami). Doboru baz do charakterystyki dokonano subiektywnie na podstawie doświadczeń autora w procesie poszukiwania własnych krewnych. Na łamach artykułu omówienie swoje znalazły zatem takie bazy, jak:

- PomGenBaza,

- GenBaza,

- Genealogia w archiwach,

- Szukaj w archiwach,

- FamilySearch,

- Geneteka.

Każdą opisywaną bazę opatrzono informacją dotyczącą m.in.: daty powstania, twórcy/twórców bazy, rodzaju gromadzonych danych, sposobów wyszukiwania i form sortowania/filtrowania wyników tego procesu, opcji rejestracji czy logowania. Wskazano także zalety i wady każdej bazy, zasygnalizowano obszary potencjalnego wykorzystania, scharakteryzowano ograniczenia i funkcjonalność. Ponadto zdefiniowano potencjalnych użytkowników baz.

W artykule celowo zrezygnowano (głównie z powodów ilościowych - artykuł zwiększyłby swoją objętość o kilkanaście stron, a także powzięto decyzji o opisaniu ich w oddzielnym tekście) z opisu kilku innych, powszechnie znanych i bez wątpienia pomocnych przy poszukiwaniach przodków baz, takich jak:

1.PRADZIAD - baza działająca pod patronatem Naczelnej Dyrekcji Archiwów Państwowych, zawierająca informacje nt. ksiąg metrykalnych i stanu cywilnego 
wszystkich archiwów państwowych, tych będących poza siecią ${ }^{8}$ dostępna pod adresem: http://baza.archiwa.gov.pl/sezam/pradziad.php.

2. Genealogia Potomków Sejmu Wielkiego i Wielka genealogia Minakowskiego - dwie bazy tworzone przez dra Marka Jerzego Minakowskiego, nazywane odpowiednio „Małą" i „Wielką". Pierwsza, darmowa, zawiera informacje nt. potomków Sejmu Wielkiego, ograniczoną do rodzin owego zgromadzenia (ponad 120 tys. osób). Druga, płatna, zawiera wywody znanych polskich osobistości „od Piasta Kołodzieja do teraz" - Kochanowski, Mickiewicz, Kopernik, Kościuszko, Kaczyńscy, Komorowski. Słynni polscy „literaci, malarze, muzycy, aktorzy, dziennikarze, odkrywcy, historycy, wojskowi, filozofowie, ludzie Kościoła, prawnicy, politycy: przedrozbiorowi, dziewiętnastowieczni, przedwojenni, powojenni, współcześni...” (ponad 700 tys. osób) 9 . Dostępne pod adresami: http://www.sejm-wielki.pl i http://wielcy.pl.

3. Baza danych programu „Straty osobowe i ofiary represji pod okupacją niemiecką" zainicjowanego w 2006 r. przez Instytut Pamięci Narodowej i Ministerstwo Kultury i Dziedzictwa Narodowego, którego podstawowym celem jest „zebranie rozproszonych informacji o ofiarach wojny i osobach represjonowanych przez okupanta niemieckiego w latach 1939-1945, przetworzenie ich na wersję elektroniczną oraz stworzenie i udostępnienie bazy danych umożliwiającej wyszukanie informacji o losach konkretnych osób" ${ }^{10}$. Dostępna jest ona w sieci internetowej pod adresem: http://www.straty.pl/index.php/szukaj-w-bazie.

Bazą szczególnie bliską autorowi, zarówno pod względem geograficznym, jak i specyfiki zasobu, od której warto rozpocząć omówienie, jest PomGenBaza - baza tworzona przez Pomorskie Towarzystwo Genealogiczne. Za datę powstania uważany jest rok 2006, kiedy koordynatorem projektu indeksowania ksiąg metrykalnych został ówczesny prezes Towarzystwa Stanisław Pieniążek. Dzisiaj koordynacja jest scedowana na dwie osoby, tj. Katarzynę Nalazek, zajmującą się wprowadzeniem do bazy informacji z metryk pelplińskich oraz Michała Wysockiego, odpowiedzialnego za wdrożenie tego procesu w gdańskich księgach metrykalnych. Sama baza powstała w ramach projektu indeksacji akt metrykalnych z zasobu Archiwum Diecezjalnego w Pelplinie, co później zaowocowało poszerzeniem pracy nad aktami metrykalnymi urzędów stanu cywilnego umieszczonymi w Archiwum Państwowym w Gdańsku. $\mathrm{Na}$ dzień 02.06.2018 r. w zbiorach bazy znajdowały się: 4669944 indeksy, z czego

\footnotetext{
${ }^{8}$ Księgi metrykalne i urzędu stanu cywilnego, [online]. Dostępny w World Wide Web: https:// www.archiwa.gov.pl/pl/dla-uzytkownikow/bazy-danych/768-księgi-metrykalne-i-stanu-cywilnego-pradziad [dostęp: 02.06.2018].

9 M.J. Minakowski, Wielka Genealogia Minakowskiego, [online]. Dostępny w World Wide Web: http://wielcy.pl/ [dostęp: 02.06.2018].

${ }^{10}$ Program Straty osobowe i ofiary represji pod okupacja niemiecka, [online]. Dostępny w World Wide Web: http://www.straty.pl/index.php [dostęp: 02.06.2018].
} 
2500875 - urodzeń, 603184 - ślubów, 1513992 - zgonów, 44774 - cmentarzy i 7119 - pomników. W bazie umieszczono także, w postaci tabeli, dane adresowe USC i biur parafialnych wraz z hiperłączami do ksiąg dostępnych w danej placówce oraz do ksiąg zindeksowanych (podzielonych według lat). Bazę można przeszukiwać według trzech indeksów/rejestrów, odnoszących się do wydarzeń z życia człowieka - chrztu, ślubu i zgonu. Dla każdej z tych możliwości stworzono formularz wyszukiwawczy, którego stałymi elementami są zawsze: zakres lat, w których dany fakt miał miejsce, rozwijana lista parafii/USC dostępnych do wyszukiwania. W obrębie poszczególnych rejestrów można dokonywać wyszukiwań na trzy sposoby:

1. Szukanie bezpośrednie (z możliwością stosowania zamienników jednej litery - „”” i dowolnego ciągu liter - „?”) - charakteryzuje się porównywaniem we wskazanym słowie, kolejno znak po znaku, co wiąże się z ograniczonym polem manewru w przypadku np. nazwisk zmieniających się na przestrzeni wieków. Przykładem może być nazwisko obecnie występujące w rodzinie autora - Stormowski, gdzie znane są jego trzy odpowiedniki, tj. Sturmowski, Szturmowski i Sztormowski.

2. Szukanie za pomocą dwóch algorytmów fonetycznych:

- Daitch-Mokotoff SOUNDEX, tzw. przeszukiwanie podobne,

- SOUNDEX, tzw. przeszukiwanie przybliżone, polega na kodowaniu słowa dla potrzeb indeksacji informacji względem ich brzmienia, a nie zapisu ${ }^{11}$.

3. Szukanie przybliżone - pozwala na porównywanie wpisanego terminu z terminami zgromadzonymi w bazie.

W formularzach wyszukiwawczych stworzonych dla poszczególnych indeksów, poza stałymi elementami wyszukiwania, umożliwiono dodatkowo wyszukiwanie według konkretnych typów informacji. I tak w przypadku:

- chrztu - jest to imię dziecka oraz imię i nazwisko ojca i matki (rys. 1),

- ślubu - są to imiona i nazwiska małżonków,

- zgonu - jest to imię i nazwisko zmarłego/zmarłej.

W każdym z wyżej wymienionych przypadków istnieje możliwość wpisania oddzielnie imienia i nazwiska, co powoduje zwiększenie liczby spływających na ekran wyników.

${ }^{11}$ A. Kamiński, Wybrane aspekty zastosowania komputera z genealogii, [online]. Dostępny w World Wide Web: http://www.ptg.gda.pl/images/Image/wyklady/Prezentacja.2006.04.01.pdf [dostęp: 02.06.2018]. 


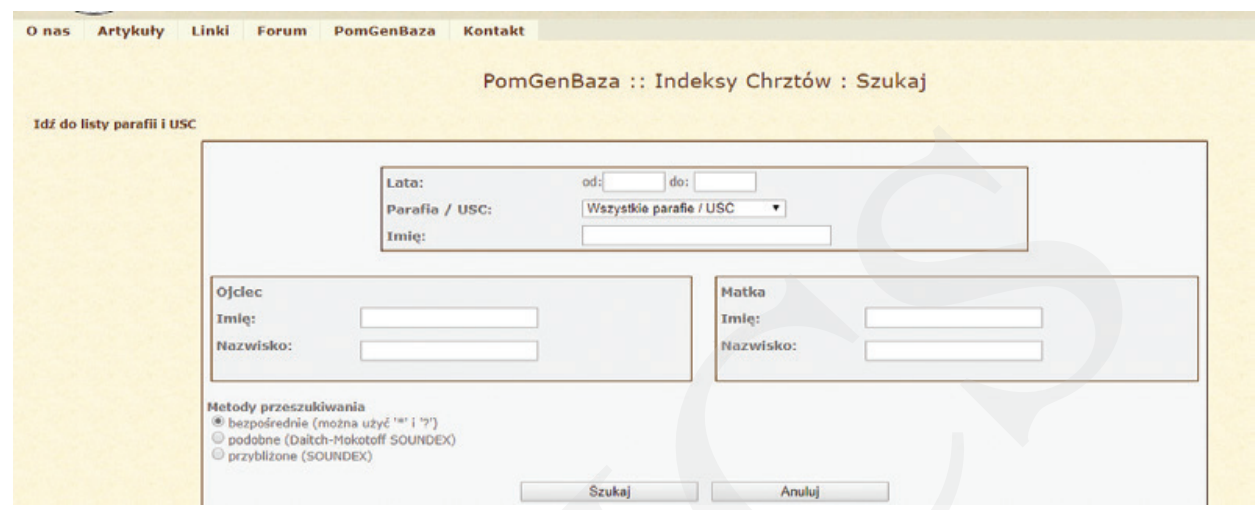

Rys. 1. PomGenBaza - formularz wyszukiwawczy do wyszukiwania chrztów.

Źródło: Indeks chrztów, [online]. Dostępny w World Wide Web: http://www.ptg.gda.pl/index.php/ certificate/action/searchB/ [dostęp: 02.06.2018].

Wynikiem każdego z trzech sposobów wyszukiwania jest lista z informacjami odnoszącymi się do poszukiwanego wydarzenia z życia (zob. rys. 2). W przypadku:

- chrztu - są to dzieci o podanym imieniu (lub zbliżonym brzmieniowo do oryginału), imiona i nazwiska rodziców, z oznaczeniami księgi i aktu,

- ślubu - są to imiona i nazwiska małżonków wraz z numerami ksiąg i aktów,

- zgonu - jest to imię i nazwisko zmarłej/zmarłego z zaznaczeniem płci i wieku w chwili śmierci, numerami księgi i aktu (rys. 2).

Niestety baza uniemożliwia sortowanie czy filtrowanie otrzymanych wyników - zachowana jest jedynie chronologia, co jest głównym wyznacznikiem kolejności wystąpień. Posiłkować się wtedy można jedynie wbudowanym narzędziem wyszukiwania w przeglądarce (CTRL + F), co jest zarówno wadą, jak i zaletą bazy. Plusem w tym przypadku jest zwiększenie możliwości odnalezienia właściwej osoby (do sprawdzenia ma się więcej informacji). Minusem z kolei - przy dużej liczbie wyników - ryzyko przeoczenia danych.

Bez wątpienia zaletą bazy PomGenBaza są otrzymane przy wyszukiwaniu informacje poboczne - często uważane tylko za pomocne, a mogące niekiedy być tymi wskazującymi przy próbach potwierdzenia prawdziwości odnalezionego pokrewieństwa czy powinowactwa. Informacjami takimi są choćby te przedstawiane w postaci ciągów liczb, np. 10_2098_0_8_0020 czy 10_2054_0_12_0007, odnośniki do bazy danych - GenBazy (zob. omówienie poniżej), przedstawiającej swoje zasoby w formie graficznej. Atutem PomGenBazy jest także prostota poruszania się po bazie, co ma ogromne znaczenie w przypadku użytkownika nieobytego $\mathrm{z}$ bazami danych. Korzystanie z bazy nie wymaga żadnej wiedzy specjalistycznej ani dodatkowych uprawnień do odczytania informacji w niej zawartych. 


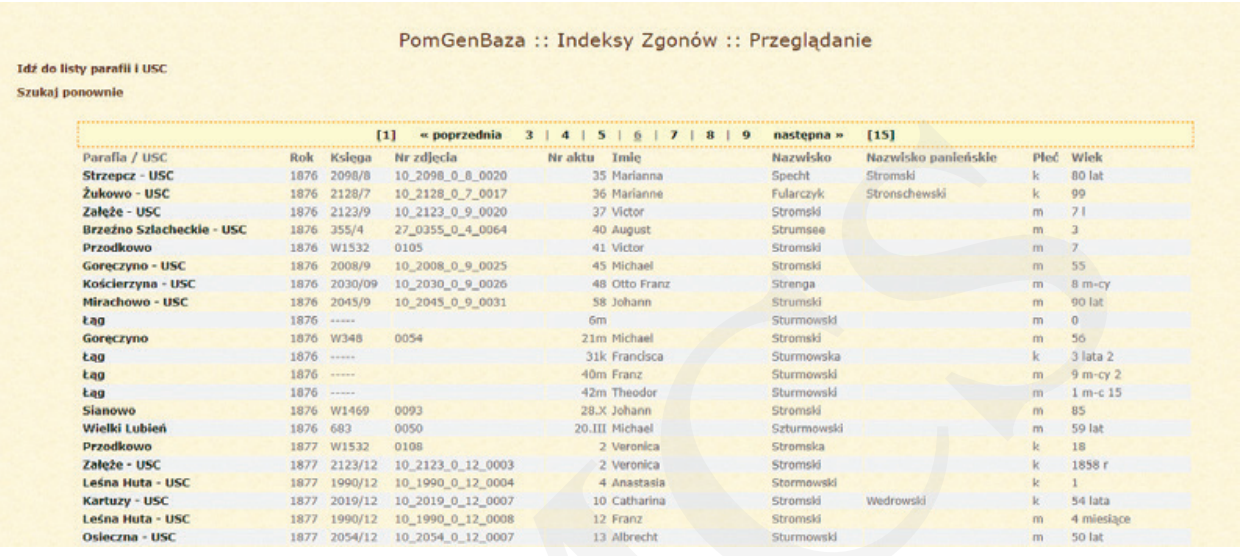

Rys. 2. PomGenBaza - przykładowy wynik wyszukiwania.

Źródło: Indeks zgonów, [online]. Dostępny w World Wide Web: http://www.ptg.gda.pl/index.php/ certificate/action/searchD/ [dostęp: 02.06.2018].

Innym rodzajem zasobu jest GenBaza ${ }^{12}$, zarządzana przez administratora Tomasza Nitscha. Bez logowania się użytkownik posiada dostęp do skanów ksiąg z archiwów państwowych z Koszalina (AP_Koszalin) i Warszawy (AP_Warszawa), a po zalogowaniu - również z Gdańska (AP_Gdańsk), Kielc (AP_Kielce), Łodzi (AP_Łódź) oraz kieleckiego archiwum diecezjalnego (AD_Kielce). Po kliknięciu na link któregokolwiek z powyższych archiwów pojawia się lista instytucji podlegających terenowo pod dane archiwum, tj. urzędów stanu cywilnego oraz parafii katolickich i ewangelickich. Te zaś dzielą się dalej na katalogi opisane latami i trzema wydarzeniami z życia człowieka, tj. chrztem, ślubem i zgonem. Kliknięcie na jakikolwiek odnośnik powoduje otwarcie zasobu ze skanami księgi metrykalnej, które są opisane według wskazanego w poprzednim akapicie ciągu numerycznego. Do bazy nie jest przypisany żaden formularz przeznaczony do wyszukiwania interesujących potencjalnego użytkownika informacji (eliminuje to również filtrowanie czy sortowanie wyników), co jest bardzo problematyczne, ponieważ aby dotrzeć do potrzebnych danych, trzeba przejrzeć każdą stronę metryki po kolei bądź znać wspomniany wyżej ciąg liczb ją identyfikujący. Często problemem jest też samo odczytanie metryki z powodu chociażby charakteru pisma urzędnika czy księdza spisującego akt lub spisania go w obcym języku - niemieckim czy rosyjskim. Wady te są rekompensowane możliwością wglądu w zeskanowany oryginał metryki urodzenia (chrztu), ślubu czy zgonu, co gwarantuje poprawność wszystkich danych

${ }^{12}$ GenBaza, [online], Dostępny w World Wide Web: http://geneteka.genealodzy.pl/ [dostęp: 02.06.2018]. 
i prawdziwość powiązania rodzinnego. Aby korzystać z całego zasobu bazy, trzeba się zarejestrować w serwisie Genpol, gdyż daje to możliwość dostępu do większości zeskanowanych metryk. Bez tego do przeglądania udostępnione są tylko dwa archiwa. Podobnie jak w przypadku PomGenBazy, przy korzystaniu z GenBazy nie jest wymagana specjalistyczna wiedza z zakresu genealogii. Wystarczy tylko znajomość kilku zasadniczych słów, wiedza, to, na które wyrażenia zwracać większą uwagę oraz które części aktu zawierają najwięcej potrzebnych informacji.

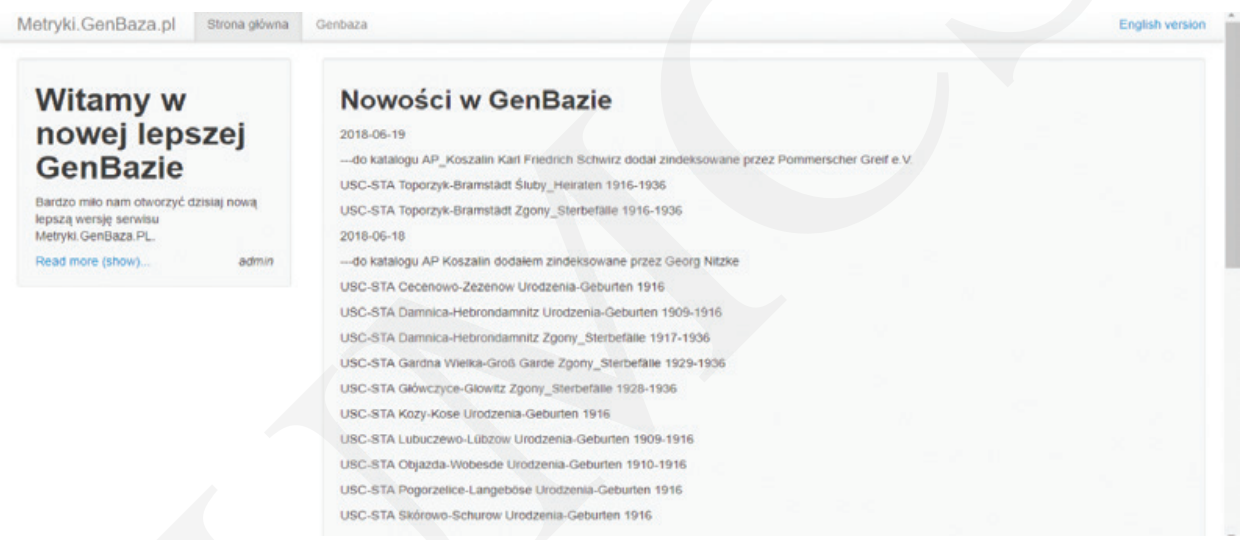

Rys. 3. GenBaza - strona główna.

Źródło: Gen Baza: Strona główna, [online]. Dostępny w World Wide Web: http://metryki.genbaza. pl/ [dostęp: 02.06.2018].

Możliwość podglądu metryk posiada również inna baza zawierająca dane w formie graficznej - Genealogia w Archiwach ${ }^{13}$. Jest ona wynikiem pracy nad projektem „Źródła genealogiczne mieszkańców województwa kujawsko-pomorskiego” współfinansowanego ze środków Unii Europejskiej w ramach „Regionalnego Projektu Operacyjnego Województwa Kujawsko-Pomorskiego na lata 2007-2013”, z zakresu „Rozwoju usług i aplikacji dla ludności”. Celem tego projektu jest „digitalizacja akt metrykalnych znajdujących się w zasobie archiwów państwowych w Toruniu i Bydgoszczy oraz udostępnianie ich w internecie w sposób umożliwiający swobodny dostęp do nich każdemu zainteresowanemu genealogią i poszukiwaniami swoich korzeni" ${ }^{14}$. Partnerem jest Naczelna Dyrekcja Archiwów Państwowych. W ramach projektu wykonano 1,8 mln skanów, co stanowi ponad 3,2 mln stron akt zgroma-

${ }^{13}$ Genealogia w Archiwach, [online]. Dostępny w World Wide Web: http://www.genealogiawarchiwach.pl [dostęp: 02.06.2018].

${ }^{14}$ Genealogia w Archiwach. Podręcznik użytkownika, [online]. Dostępny w World Wide Web: https://www.genealogiawarchiwach.pl/APP/global/0/legacy/0/Podręcznik.pdf [dostęp: 08.06.2018]. 
dzonych w obu archiwach. Obecnie baza zawiera: 3248294 skany, 37783 księgi, 473 zespoły archiwalne i 757282 indeksy $^{15}$.

Wyszukiwanie w bazie odbywa się na dwa sposoby - proste i zaawansowane. Pierwsze z nich polega na wpisaniu poszukiwanego nazwiska i/lub nazwy dokumentu oraz zatwierdzeniu wyszukiwania. Dodatkowo w oknie obok można wpisać nazwę miejscowości, której ma ono dotyczyć. Zaawansowana wersja różni się tym, że okno wyszukiwawcze jest podzielone na cztery części, tj. pole do wpisania nazwiska, pole do wpisania imienia oraz dwie listy rozwijane z rodzajem aktu (urodzenia, zgonu, małżeństwa) oraz relacjami rodzinnymi (zmarły, dziecko, matka, ojciec, panna młoda, pan młody, wszystkie). Wynikiem wyszukiwania są kafelki z opisanymi jednostkami archiwalnymi, z których opisu można wyczytać nazwy miejscowości, gminy i województwa, w której się ona znajduje, nazwę zespołu archiwizującego, miejsce przechowywania, nazwę rejestru, kategorię, sygnaturę, datę i rodzaj aktu. Na rysunku 4, oddzielone poziomą kreską, znajdują się wymienione z imienia i nazwiska osoby zindeksowane w danej jednostce archiwalnej. Na każdym kafelku w jego górnej części widnieją trzy ikony (widokówka, prostokąt ze strzałką oraz grupa trzech osób) symbolizujące: dokładne informacje o dokumencie, te same informacje, ale w linku zewnętrznym oraz dokładne informacje o zespole archiwalnym. Po lewej stronie otrzymanych wyników znajduje się formularz do sortowania/filtrowania wyników według daty, województwa, miejscowości, gminy, archiwum, kategorii, rodzaju aktu, zespołu, indeksów, stanu digitalizacji, rodzaju zasobu, ostatnio dodanych jednostek archiwalnych. Po wyborze ikony widokówki zostaje załadowany podgląd pliku graficznego wraz z opisem danych transliterowanych $\mathrm{z}$ aktu. Często sam akt jest $\mathrm{w}$ innym języku (np. niemieckim pisanym czcionką w stylu gotyckim), co stwarza problemy z poprawnym odczytaniem metryki. Pomocna wtedy staje się zakładka Tłumaczenie, z przetłumaczonymi stałymi elementami tekstu. Użytkownik może taki plik zapisać na dysku swojego komputera, powiększyć, pomniejszyć, obrócić o $90^{\circ} \mathrm{w}$ prawo/lewo, co w znacznym stopniu ułatwia pracę, gdyż nie trzeba ponownie ładować skanu, poszukiwać odpowiedniego wpisu i próbować go odczytać - można to zaznaczyć w pobranym pliku. Dodatkową zaletą są indeksy osób umieszczanych w aktach, wraz z osobami najbliższymi, tj. rodzicami i chrzestnymi (przy aktach urodzenia), świadkami (przy aktach małżeństwa). Niestety, nie wszystkie dane z aktów są zindeksowane, co powoduje nie lada problemy z korzystaniem z bazy (niewyraźne pismo odręczne urzędnika). Wadą w przypadku tej bazy jest także wybiórczość indeksowania spowodowana ciągłymi pracami nad udoskonaleniem zasobu. Osoba korzystająca z bazy powinna umieć rozczytać ówczesne pismo, wiedzieć, które miejsca w akcie są ważne i na które zwrócić wyjątkową uwagę.

\footnotetext{
15 Stan na 13.06.2018 r.
} 
Pobrane z czasopisma Folia Bibliologica http:/foliabibliologica.umcs.pl

Data: 26/04/2023 17:10:07

Bazy genealogiczne jako pomoc w poszukiwaniu przodków

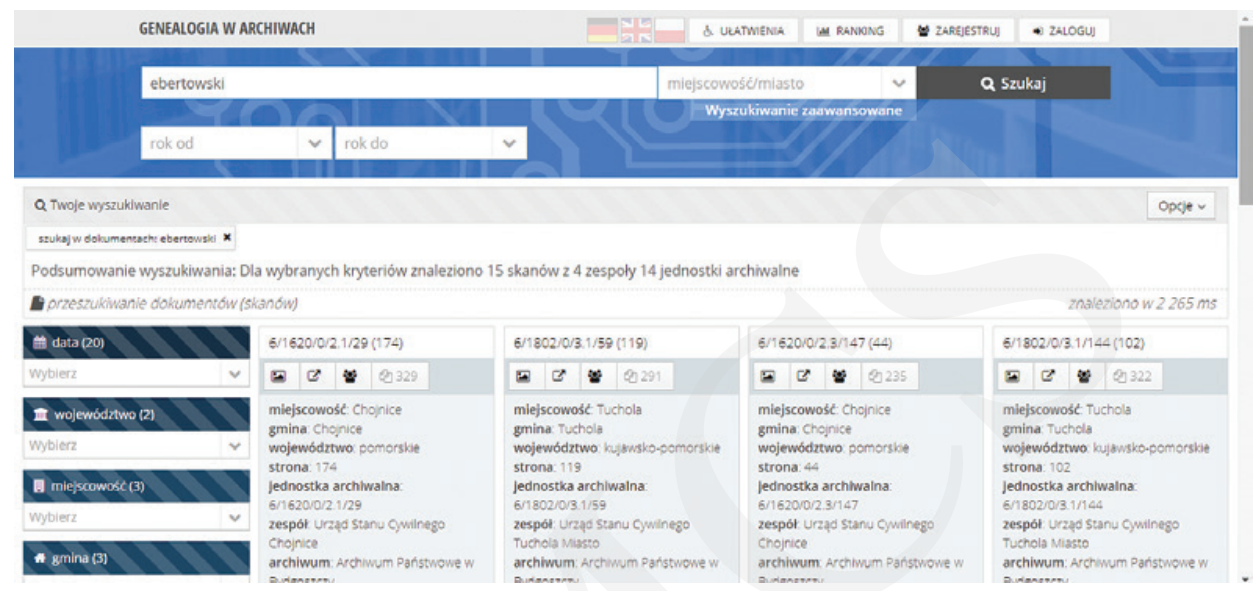

Rys. 4. Genealogia w archiwach - wynik przykładowego wyszukiwania.

Źródło: Genealogia w Archiwach: „ebertowski”, [online]. Dostępny w World Wide Web: https:// www.genealogiawarchiwach.pl/\#query.query=ebertowski\&query.suggestion=false\&query.thumbnails=false\&query.facet=true\&query.sortMode=DEFAULT\&goComments=false [dostęp: 08.06.2018].

Kolejną wartą omówienia bazą jest baza Szukaj w Archiwach ${ }^{16}$, przechowywująca w swoich zasobach nie tylko informacje z zakresu genealogii, ale również opisy innych materiałów archiwalnych $z$ archiwów państwowych i innych instytucji. Zgodnie z komunikatem zamieszczonym na stronie internetowej: „Materiały, które znajdziesz na szukajwarchiwach.pl możesz swobodnie wykorzystywać, w tym pobierać, kopiować i rozpowszechniać" ${ }^{17}$. Pomysłodawcą i autorem wprowadzonego po raz pierwszy w 2009 r. serwisu jest Narodowe Archiwum Cyfrowe. Obecnie w bazie publikuje 79 instytucji, mieści się 12 mln opisów materiałów archiwalnych i ponad $30 \mathrm{mln}$ skanów materiałów archiwalnych ${ }^{18}$. Zbiory zawierają wybrane archiwalia z systemu gromadzenia danych ZOSiA (Zintegrowany System Informacji Archiwalnej) oraz przywoływanej już w artykule bazy PRADZIAD. Instytucjami publikującymi w serwisie są przede wszystkim: Archiwum Główne Akt Dawnych, Archiwum Akt Nowych i Narodowe Archiwum Cyfrowe oraz 30 oddziałów Archiwum Państwowego, a także spoza sieci archiwów państwowych: Archiwum Instytutu Hoovera, Archiwum Muzeum Zamoyskich w Kozłówce, Archiwum Muzeum Narodowego w Krakowie, Archiwum Biblioteki Polskiej im. Ignacego Domeyki,

${ }^{16}$ Szukaj w Archiwach, [online]. Dostępny w World Wide Web: http://www.szukajwarchiwach. pl [dostęp: 08.06.2018].

17 Szukaj w Archiwach: O serwisie, [online]. Dostępny w World Wide Web: http://www.szukajwarchiwach.pl/o_serwisie [dostęp: 13.06.2018].

18 Stan na 13.06.2018 r. 
Archiwum Fundacji Kultury i Dziedzictwa Ormian Polskich, Centralne Muzeum Jeńców Wojennych w Łambinowicach-Opolu, Muzeum Romantyzmu w Opinogórze, Archiwum Polskiej Misji Katolickiej w Szwajcarii.

Baza oferuje dwie możliwości przeszukiwania bazy - proste i zaawansowane. Obydwa sposoby polegają na wpisaniu interesującego użytkownika słowa w pole wyszukiwawcze i zatwierdzeniu go, przy czym dla wyszukiwania zawansowanego dodano różnego rodzaju filtry (zawierające pola specjalistyczne umożliwiające zawężenie wyników wyszukiwania lub wyświetlenia konkretnej informacji; filtry zespołu, jednostek, obiektów i aktów metrykalnych) i opcje przeglądania (umożliwiają zawężenie zakresu wyszukiwania do poziomu zespołu, jednostki czy obiektu). Zarówno w formie prostej, jak i zaawansowanej jest możliwe wyszukiwanie danych zawierających tylko jednostki/zespoły ze skanami. Dodatkowym atutem filtrowania jest dodanie oznaczeń za pomocą czterech kolorów, gdzie każdy oznacza hierarchię/zakres filtra, tzn.: czerwień - zespół, zieleń - jednostka, błękit - obiekt, granat - akt metrykalny i stanu cywilnego. Wynikiem wyszukiwania jest lista skróconych rekordów, w których występuje wpisane wcześniej słowo. Kluczowa jest liczba znajdująca się w prawym górnym rogu każdego wyniku, oznaczająca liczbę skanów z danej jednostki aktowej. Rezultaty wyszukiwania można również sortować według trafności oraz rosnąco lub malejąco według: sygnatury, daty początkowej, daty końcowej, tytułu i pola dat skrajnych. Po kliknięciu w którykolwiek wyszukany rekord pojawi się z opisem danej jednostki archiwalnej z podaną sygnaturą, stanem fizycznym, formą zewnętrzną, wymienionym językiem oryginału. Na tej samej stronie nad opisem, obok podświetlonej na czerwono sygnatury jest odnośnik do skanów wraz z podaną ich liczbą. Baza do obsługi nie wymaga znajomości specjalistycznej wiedzy genealogicznej. Jest nastawiona na odbiorcę ogólnego, potencjalnego poszukiwacza przodków.

Niektóre z polskich towarzystw genealogicznych udostępniają wyniki swojej pracy na serwerach innych instytucji związanych z genealogią, posiadających większy zasięg działania i odbioru przez użytkowników. Przykładami instytucji podejmujących takie działania są m.in.: Towarzystwo Genealogiczne Ziemi Częstochowskiej i Lubelskie Towarzystwo Genealogiczne. Oba stowarzyszenia działają w oparciu o serwis FamilySearch, zarządzany przez organizację (największą genealogiczną na świecie, gdzie miliony osób korzysta z jej rekordów, zasobów i usług ${ }^{19}$ ) o tej samej nazwie, powstałą dzięki Kościołowi Jezusa Chrystusa Świętych w Dniach Ostatnich, którego wyznawców potocznie nazywa się mormonami. Serwis oferuje darmowy dostęp dla wszystkich użytkowników (po uprzednim zalogowaniu się). Indeksuje imiona $\mathrm{z}$ całego świata (w liczbie ponad 4 mld), posiada 4725 centra FamilySearch

19 About FamilySearch, [online]. Dostępny w World Wide Web: https://www.familysearch.org/ home/about [dostęp: 15.06.2018]. 
Pobrane z czasopisma Folia Bibliologica http:/foliabibliologica.umcs.pl

Data: 26/04/2023 17:10:07

Bazy genealogiczne jako pomoc w poszukiwaniu przodków

Szukana fraza: ebertowski
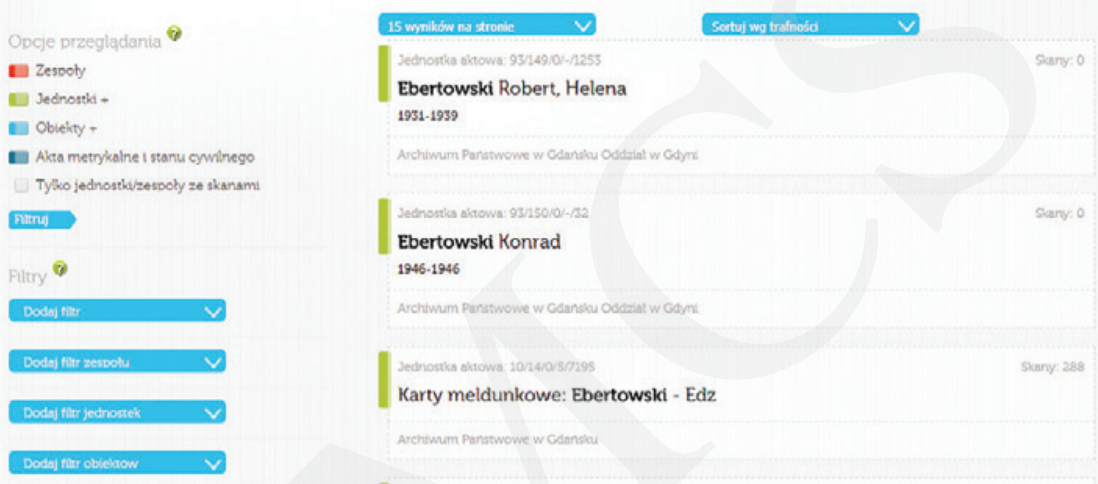

Rys. 5. Szukaj w Archiwach - przykładowa lista wyników wyszukiwania.

Źródło: Szukaj w Archiwach: „ebertowski”, [online]. Dostępny w World Wide Web: https://szukajwarchiwach.pl/search?q=ebertowski [dostęp: 13.06.2018].

\section{Karty meldunkowe: Ebertowski - Edz}

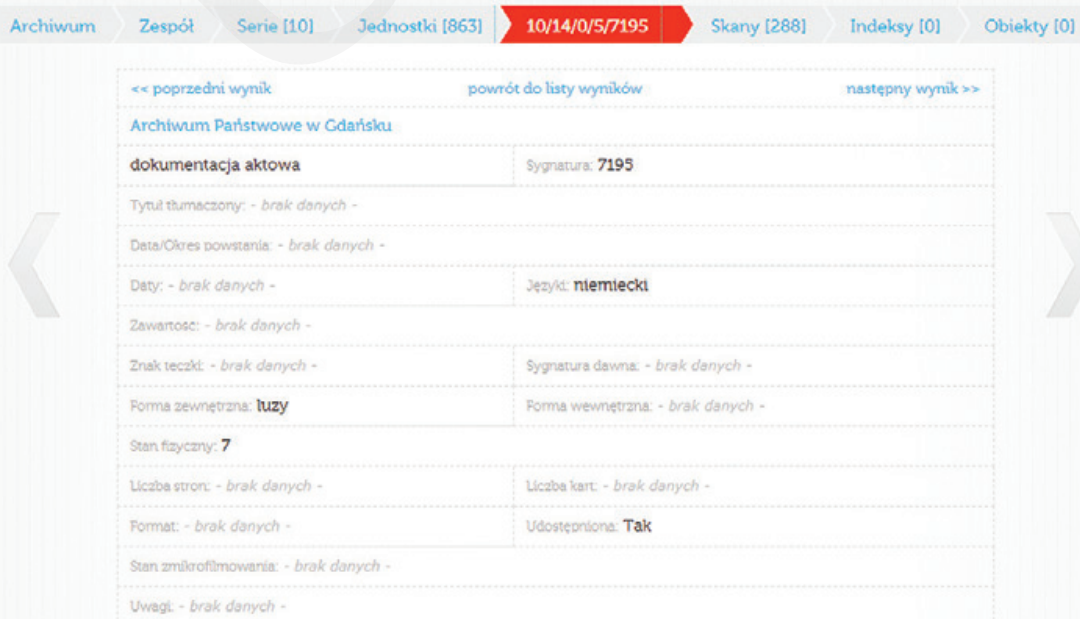

Rys. 6. Szukaj w Archiwach - opis jednostki archiwalnej.

Źródło: Szukaj w Archiwach: Karty meldunkowe: Ebertowski - Edz, [online]. Dostępny w World Wide Web: https://szukajwarchiwach.pl/10/14/0/5/7195?q=ebertowski\&wynik=3\&rpp=15\&page $=1 \#$ tabJednostka [dostęp: 13.06.2018]. 
na całym świecie (4 w Polsce: Bydgoszcz, Łódź, Warszawa i Wrocław) i bezpłatną pomoc telefoniczną ekspertów przez 24 godziny na dobę 7 dni w tygodniu. Stronę uruchomiono w 1999 r., zapewniając narzędzie online służące do łatwiejszego udostępniania historii rodziny szerszej publiczności w dowolnym miejscu na świecie, bez żadnych kosztów ${ }^{20}$.

Przeszukiwanie serwisu odbywa się na kilka sposobów. Za domyślną metodę przyjęto poszukiwanie osoby zmarłej za pomocą imienia i nazwiska. Dodatkowymi aspektami tego sposobu wyszukiwania są:

- opcje wyboru wydarzenia z życia poszukiwanej jednostki, na którym najbardziej zależy szukającemu, tj. narodziny, małżeństwo, miejsce zamieszkania/pobytu, śmierć i wszystkie wyżej wymienione. Każde z nich po zaznaczeniu rozwija listę, gdzie można wpisać miejsce zdarzenia i zakres lat;

- szukanie relacji, powiązań rodzinnych poszukiwanej osoby względem innych. Do wyboru są trzy rodzaje relacji: małżeństwo, rodzicielstwo i inne osoby. Po zaznaczeniu rozwija się lista z miejscem do wpisania odpowiednio: imienia i nazwiska małżonka, imienia i nazwiska matki i ojca oraz imienia i nazwiska innej osoby.

Podczas tego sposobu wyszukiwania już na etapie wprowadzania danych można ograniczyć wyniki wyszukiwania do lokalizacji (wpisując kraj i miasto), rodzaju wydarzenia (zaznaczając z rozwiniętej listy spośród narodzin, chrztu, małżeństwa, zgonu, spisu ludności, miejsca zamieszkania, imigracji, naturalizacji, służby wojskowej, potwierdzonej autentyczności dokumentu i innych), numeru partii i numeru mikrofilmu (wpisując numery).

Drugą możliwością przeszukiwania bazy jest badanie według lokalizacji. Umożliwia to mapa świata z zaznaczonymi regionami. Do wyboru są: Kanada, USA, Meksyk, kraje Ameryki Środkowej, Ameryka Południowa, Europa (bez Wielkiej Brytanii, ale z Rosją), Wielka Brytania, Azja (bez Rosji), Australia z Nową Zelandią, Oceania, Afryka. Kliknięcie na którykolwiek region spowoduje rozwinięcie listy z nazwami krajów z danego regionu do wyboru. Zaznaczając odpowiednie państwo, wyświetla się okno z pierwszym sposobem wyszukiwania, ale już w zakresie danego terytorium.

Trzecią formą poszukiwań są kolekcje, gdzie po prostu wpisuje się nazwę pożądanej kolekcji.

Wynikiem wyszukiwania jest tabela składająca się z czterech kolumn, w której kolejno w każdym wierszu umieszczono wiadomości o znalezionych osobach, tj. nazwa (imię i nazwisko, powiązanie z innymi osobami występującymi w spisie, nazwa spisu), wydarzenie skojarzone $\mathrm{z}$ daną osobą (data i miejsce urodzenia oraz

${ }^{20}$ Archives. About, [online]. Dostępny w World Wide Web: https://www.familysearch.org/records/archives/web/about-timeline/ [dostęp: 15.06.2018]. 

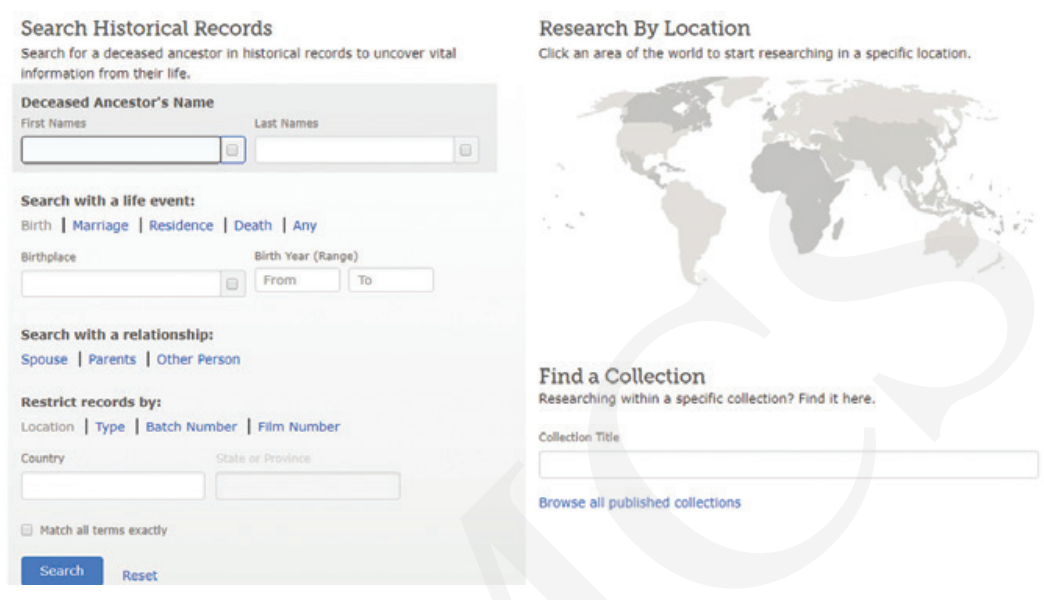

Rys. 7. Trzy sposoby wyszukiwania w bazie FamilySearch.

Źródło: FamilySearch: Search, [online]. Dostępny w World Wide Web: https://www.familysearch. org/search [dostęp: 15.06.2018].

zamieszkania w momencie tworzenia spisu), relacje względem innych osób w rodzinie (rodzice, małżonek/małżonka, dzieci) oraz opis dokumentacji wraz z reprezentacją graficzną zeskanowanej strony spisu. Kliknięcie w imię i nazwisko danej osoby powoduje wyświetlenie rozwijanej listy z podstawowymi informacjami jej dotyczącymi (np. kolor skóry, miejsce urodzenia czy ostatnie miejsce zamieszkania) oraz zestawienia zawierającego dane członków rodziny z odnośnikami do ich relacji rodzinnych. Baza jest bardzo intuicyjna. Przez różne metody filtrowania i sortowania wyników daje mnóstwo możliwości wyszukania konkretnych osób. Może to jednak powodować zbytnie skupienie na konkretnym aspekcie z życia poszukiwanej osoby, co może być złudne w przypadku, gdy np. aspekt ten nie jest odnotowany w bazie. Liczba czterech miliardów rekordów jest niewątpliwie kolejną zaletą bazy, co równoważy się z utrudnieniem w postaci angielskiej wersji bazy. Serwis jest tak skonstruowany, aby mogła z niego skorzystać każda osoba zainteresowana poszukiwaniami genealogicznymi, nawet ta nieposiadająca specjalistycznej wiedzy z zakresu genealogii.

Ostatnią omawianą bazą jest stworzona przez Jacka Młochowskiego w $2006 \mathrm{r}$. Geneteka $^{21}$. Powstała ona jako realizacja dwóch pasji - informatycznej administratora strony polskiego wsparcia CMS-a postnuke i genealogicznej użytkownika forum na portalu GenPol, a inspiracją był projekt Marka Minakowskiego

${ }^{21}$ Geneteka, [online]. Dostępny w World Wide Web: http://www.geneteka.genealodzy.pl [dostęp: 15.06.2018]. 
- Ogólnopolski Indeks Małżeństw do 1899 r. ${ }^{22}$ Baza rejestruje i udostępnia dane w podobny sposób jak PomGenBaza, tj. w wersji tekstowej, aczkolwiek niekiedy w postaci dołączonych skanów metryk umieszczonych w innej wspomnianej bazie - Szukaj w Archiwach. W bazie są przechowywane informacje zindeksowane z trzech rodzajów metryk: urodzeń, ślubów i zgonów z terenów całej Polski oraz Litwy, Białorusi i Ukrainy.

Wyszukiwanie rozpoczyna się od wyboru na mapie Polski odpowiedniego regionu czy województwa lub wyboru jednego z trzech wcześniej wspomnianych krajów. Zaowocuje to przejściem do ekranu wyszukiwania, gdzie do wyboru zaoferowano kilka innych funkcji zawężania poszukiwań. Po wyborze terenu, który chcemy przeszukiwać, można dokonać uściślenia do konkretnej parafii podanej w rozwijanej liście (lista zawiera również zakresy dat ksiąg metrykalnych zindeksowanych w ramach bazy). Niżej znajduje się miejsce na wpisanie interesujących użytkownika nazwisk i imion. Obok umieszczono dodatkowe warianty wyszukiwania, tj. zakres dat oraz możliwości zaznaczenia takich opcji, jak wyszukiwanie dokładne, wyszukaj jako para, nie wyszukuj w rodzicach, wyszukaj również w pobliskich parafiach $(15 \mathrm{~km})$ i wyszukaj tylko indeksy $\mathrm{z}$ ostatnich dni (gdzie z rozwijanej listy można wybrać $1,3,7,14,31$ i 60 dni).

Wynikiem wyszukiwania są trzy listy pogrupowane w zakładkach: chrzty, małżeństwa i zgony. Każda z list jest ułożona chronologicznie, w których w kolumnach podano informacje o:

- dla urodzeń: rok, akt, imię, nazwisko, imię ojca, imię matki, nazwisko matki, parafia, miejscowość i uwagi,

- dla małżeństw: rok, akt, imię, nazwisko, rodzice pana młodego, imię, nazwisko, rodzice pani młodej, parafia i uwagi,

- dla zgonów: rok, akt, imię, nazwisko, imię ojca, imię matki, nazwisko matki, parafia, miejscowość i uwagi.

W uwagach zazwyczaj są informacje oznaczone czterema ikonkami (i, Z, A, i SKAN), dotyczącymi dodatkowych informacji o źródle metryki, miejscu przechowywania oryginału aktu, osobie indeksującej metryki oraz ewentualnym skanie dokumentu. Listę wyników można również przeszukiwać oraz zarządzać liczbą wyświetlanych pozycji (10, 25 i 50 wierszy).

${ }^{22}$ Historia Geneteki, [online]. Dostępny w World Wide Web: http://geneteka.genealodzy.pl/ogenetece.php [dostęp: 15.06.2018]. 


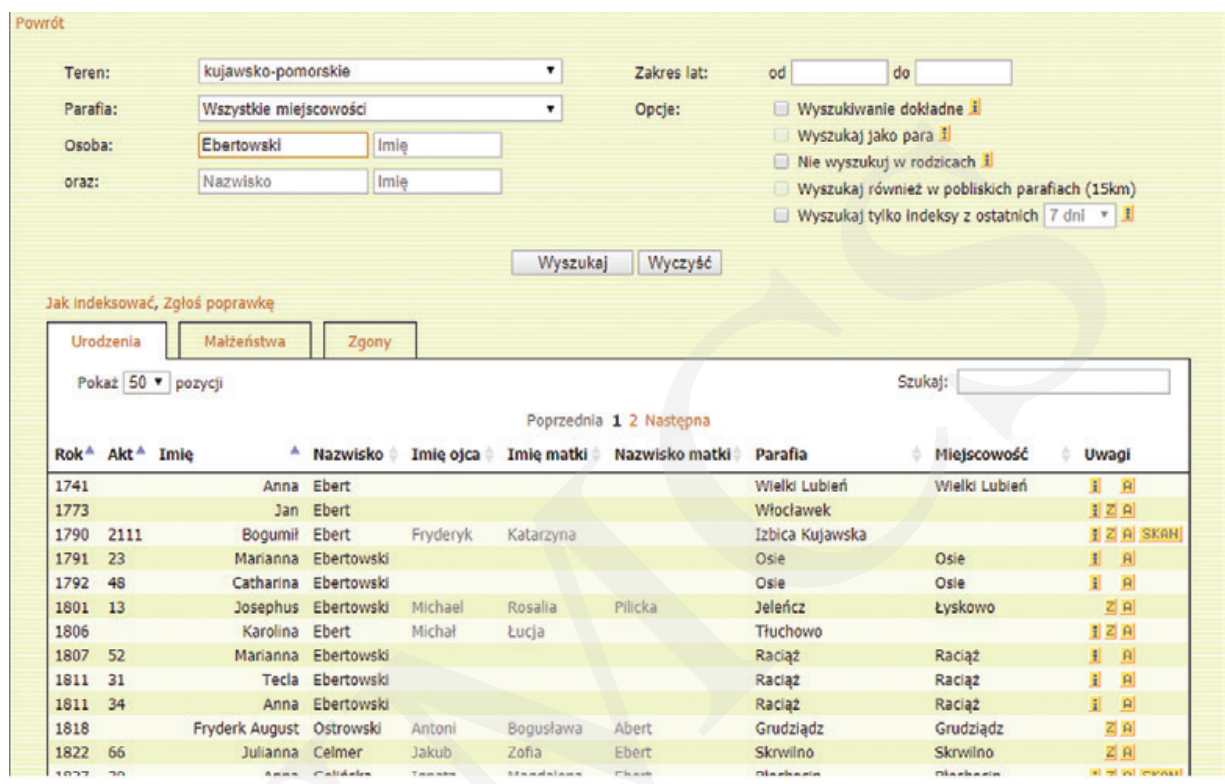

Rys. 8. Geneteka - formularz wyszukiwania wraz z listą wyników.

Źródło: Geneteka: „Ebertowski”, [online]. Dostępny w World Wide Web: http://geneteka.genealo-

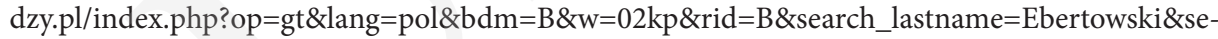
arch_name=\&search_lastname2 $=\& s e a r c h \_n a m e 2=\& f r o m \_d a t e=\&$ to $\_d a t e=[d o s t e ̨ p: 15.06 .2018]$.

Potencjalny użytkownik raczej nie będzie miał problemów z obsługą Geneteki, gdyż baza jest skonstruowana w bardzo prosty, intuicyjny sposób. Wyniki wyświetlają się w formie przejrzystej i zrozumiałej dla odbiorcy, co nie stwarza dodatkowych kłopotów z ich odczytaniem. Nie jest też potrzebna specjalistyczna wiedza z zakresu genealogii, co czyni bazę jeszcze bardziej atrakcyjną pod względem użyteczności i dostępności do wiedzy o przodkach.

\section{Podsumowanie}

Genealogiczne bazy danych są skarbnicą wiedzy o rodzinie, przodkach, szczególnie dla genealogów zaczynających przygodę z tworzeniem własnego drzewa genealogicznego. Każda z opisanych baz jest na swój sposób wartościowa i potrzebna. Mimo wielu wad, jak chociażby brak możliwości przeszukiwania (GenBaza), obcojęzyczny interfejs (FamilySearch) czy brak niektórych indeksów (Genealogia w Archiwach), nadrabiają one ogromem danych w nich zawartych, bezpłatnym dostępem oraz możliwością porównania zebranych informacji z zeskanowanym 
oryginałem metryki dzięki odpowiednim oznaczeniom (PomGenBaza i Geneteka przy współpracy z GenBazą i Szukaj w Archiwach). Potencjalny użytkownik nie musi posiadać specjalistycznej wiedzy z zakresu genealogii, aby swobodnie się po nich poruszać. Różne możliwości wyszukiwania, przejrzystość wyników, ich czytelność, możliwości filtrowania i sortowania są dodatkowymi atutami opisanych baz. Kwestią wyboru użytkownika jest to, która baza będzie mu bardziej potrzebna oraz w której znajdzie więcej informacji go interesujących. Wszystkie są jednak godne polecenia, chociażby dlatego że dostęp do nich jest bezpłatny i bardzo prosty. Ponieważ każda z nich oferuje nieco inne zasoby, w poszukiwaniu przodków warto stosować wyszukiwanie zaawansowane lub krzyżowe, mające na celu przeszukiwanie różnych zasobów z zastosowaniem wielu dodatkowych kryteriów ${ }^{23}$.

Oczywiście dziewięć przywołanych w artykule baz (sześć opisanych szerzej i trzy wspomniane) stanowi tylko niewielką częścią genealogicznych zasobów Internetu. $\mathrm{Z}$ uwagi na fakt, że dziś prawie każda organizacja związana z poszukiwaniem przodków posiada swoje forum, na którym osoby już zaangażowane w proces poszukiwania krewnych chcą pomóc innym, dzieląc się swoją wiedzą i umiejętnościami oraz porównują wyniki swojej pracy, przy poszukiwaniu przodków warto więc pamiętać także i o nich.

\section{Bibliografia}

About FamilySearch, [online]. Dostępny w World Wide Web: https://www.familysearch.org/ home/about [dostęp: 15.06.2018].

Archives. About, [online]. Dostępny w World Wide Web: https://www.familysearch.org/ records/archives/web/about-timeline/ [dostęp: 15.06.2018].

Banachowski L., Stencel K., Bazy danych. Projektowanie aplikacji na serwerze, Warszawa 2001.

Człowiek i społeczeństwo. Wizualne bazy danych, red. M. Krajewski, Poznań 2013.

GenBaza, [online]. Dostępny w World Wide Web: http://www.metryki.genbaza.pl [dostęp: 02.06.2018].

Genealogia w Archiwach, [online]. Dostępny w World Wide Web: http://www.genealogiawarchiwach.pl [dostęp: 02.06.2018].

Genealogia w Archiwach. Podręcznik użytkownika, [online]. Dostępny w World Wide Web: https://www.genealogiawarchiwach.pl/APP/global/0/legacy/0/Podręcznik.pdf [dostęp: 08.06.2018].

Geneteka, [online]. Dostępny w World Wide Web: http://www.geneteka.genealodzy.pl [dostęp: 15.06.2018].

\footnotetext{
${ }^{23}$ J. Rzymełka, Sztambuch rodzinny, czyli w poszukiwaniu własnych korzeni, Katowice 2016, s. 10.
} 
Historia Geneteki, [online]. Dostępny w World Wide Web: http://geneteka.genealodzy.pl/ ogenetece.php [dostęp: 15.06.2018].

Kamiński A., Wybrane aspekty zastosowania komputera z genealogii, [online]. Dostępny w World Wide Web: http://www.ptg.gda.pl/images/Image/wyklady/Prezentacja.2006.04.01.pdf [dostęp: 02.06.2018].

Kowalska M., Zasoby czasopiśmiennicze w polskich bibliotekach cyfrowych i bibliograficznych bazach danych - koegzystencja, konkurencja czy kooperacja?, [w:] Bibliograficzne bazy danych: kierunki rozwoju i możliwości współpracy, Ogólnopolska konferencja naukowa z okazji 10-lecia bazy danych BazTech. Bydgoszcz, 27-29 maja 2009 r., [online]. Dostępny w World Wide Web: http://www.ebib.pl/publikacje/matkonf/mat19/ kowalska.php [dostęp: 27.05.2018].

Księgi metrykalne i urzędu stanu cywilnego, [online]. Dostępny w World Wide Web: https:// www.archiwa.gov.pl/pl/dla-uzytkownikow/bazy-danych/768-księgi-metrykalne-i-stanu-cywilnego-pradziad [dostęp: 02.06.2018].

Minakowski M.J., Wielka Genealogia Minakowskiego, [online]. Dostępny w World Wide Web: http://wielcy.pl/ [dostęp: 02.06.2018].

Program "Straty osobowe i ofiary represji pod okupacja niemiecka", [online]. Dostępny w World Wide Web: http://www.straty.pl/index.php [dostęp: 02.06.2018].

Rojek-Mikołajczak I., Bazy danych. Kurs dla inżynierów informatyki, Bydgoszcz 2004.

Rzymełka J., Sztambuch rodzinny, czyli w poszukiwaniu własnych korzeni, Katowice 2016.

Szukaj w Archiwach, [online]. Dostępny w World Wide Web: http://www.szukajwarchiwach. pl [dostęp: 02.06.2018].

Szukaj w Archiwach: O serwisie, [online]. Dostępny w World Wide Web: http://www.szukajwarchiwach.pl/o_serwisie [dostęp: 13.06.2018].

Urbanowicz P., Płonkowski M., Urbanowicz D., Bazy danych. Teoria i praktyka. Podręcznik dla studentów szkół wyższych, Lublin 2010. 